\title{
MOLECULAR CHARACTERIZATION OF RHODOCOCCUS EQUI ISOLATES OF HORSE BREEDING FARMS FROM AN ENDEMIC REGION IN SOUTH OF BRAZIL BY MULTIPLEX PCR
}

\author{
Cristina da Costa Krewer ${ }^{1}$; Dênis Augusto Spricigo ${ }^{1}$; Sônia de Avila Botton ${ }^{1}$; \\ Mateus Matiuzzi da Costa ${ }^{2}$; Irene Schrank ${ }^{3}$; Agueda Castagna de Vargas ${ }^{1 *}$
}

\begin{abstract}
${ }^{1}$ Universidade Federal de Santa Maria, Departamento de Medicina Veterinária Preventiva, Laboratório de Bacteriologia, Santa Maria, RS, Brasil; ${ }^{2}$ Fundação Universidade do Vale do São Francisco, Zootecnia, Petrolina, PE, Brasil; ${ }^{3}$ Universidade Federal do Rio Grande do Sul, Centro de Biotecnologia, Porto Alegre, RS, Brasil.
\end{abstract}

Submitted: February 05, 2007; Returned to authors for corrections: May 05, 2007; Approved: January 19, 2008.

\begin{abstract}
Rhodococcus equi is a gram-positive coco-bacillus and an intracellular opportunistic pathogen which causes pneumonia in foals. It is widely detected in environment and has been isolated from several sources, as soil, feces and gut from health and sick foals. The goal of this study was to characterize the epidemiological status (endemic, sporadic or no infection) of horse breeding farms from Bage County in South of Brazil, using a multiplex PCR. One hundred and eighteen $R$. equi isolates were identified by biochemical tests and submitted to a specie-specific and vapA multiplex PCR. These isolates were obtained from: three farms where the R. equi infection has been noticed, two farms where the disease has been not reported and one farm where the disease is frequent. All clinical isolates from horse breeding farms where the disease is endemic and/or sporadic were $v a p A$-positive. None environmental isolates were $v a p A$-positive. In three horse breeding farms with sporadic $R$. equi infection, $11.54 \%$ of the isolates from adult horse feces were vapA-positive. The multiplex PCR technique has proven to be effective for the molecular and epidemiological characterization of the $R$. equi isolates in horse breeding farms. An important finding in this study was the isolation of vapApositive $R$. equi from adult horse feces, which is an evidence for other routes of dissemination of this pathogen in the farms.
\end{abstract}

Key-words: Rhodococcus equi, Multiplex PCR, bronchopneumonia, epidemiology

\section{INTRODUCTION}

Rhodococcus equi causes a very important disease in horses around the world. Virulent Rhodococcus equi strains are associated to bronchopneumonia, ulcerative lymphangitis, internal abscess, diarrhea and pleurisy in foals (23). The bacterium is a gram-positive intracellular opportunistic pathogen. It is widely spread in the environment and commonly isolated from soil, feces and gut from healthy and sick animals $(8,15,24)$.

Rhodococcosis is endemic in some farms, sporadic in others and not reported in most of them. The epidemiologic status depends on farm management, foal population density and use of dusty floors in foaling stalls (3). Additionally, environmental issues such as temperature, humidity, dust, and soil $\mathrm{pH}$ can influence the development of this infection $(12,13)$. Furthermore, the virulence of $R$. equi strains in a farm, especially those found in the soil and foal feces is the most important concern of this disease (14).

$R$. equi virulence is associated to the bacterium ability to prevent the phagosome-lysosome fusion and multiplication in macrophages, resisting to clearance by the organism defenses (8). The virulence factor associated to $R$. equi infection in foals is a thermorregulated virulence-associated antigen (VapA), encoded by vapA gene, located in the $85-90 \mathrm{~Kb}$ virulence plasmid (2). According to many researchers the 15 - 17kDa VapA antigen is found in all clinical R. equi isolates from foals, as well in some

*Corresponding Author. Mailing address: Universidade Federal de Santa Maria. Departamento de Medicina Veterinária Preventiva. Laboratório de Bacteriologia. Av. Roraima, Campus Universitário. Prédio 44, Sala 5137, Santa Maria, RS, Brasil; Fone (55) 3220 8107. E-mail: agueda@ccr.ufsm.br 
environmental samples $(4,20)$. The importance of vapA gene in the pathogenesis of $R$. equi infection and its use as an epidemiological marker of bacterium virulence are well established since all strains carrying the vapA gene are lethal to mice and foals $(4,11,19,21)$.

The goal of this study was to perform the genotypic characterization of $R$. equi isolates and determine the epidemiological status (endemic, sporadic or no infection) of horse breeding farms from Bage County, RS, Brazil.

\section{MATERIALS AND METHODS}

\section{Bacterial Strains}

This study was conducted with 118 bacterial isolates previously classified as $R$. equi by biochemical tests (9), collected in six horse breeding farms (Table 1). The strains have been isolated from horse feces (41 from adults and 33 from foals), soil (21), foaling stalls (10) and other domestic animals (3). Other 10 clinical isolates were cultivated from lungs of sick foals. $R$. equi ATCC 33701P+ (vapA positive) and $R$. equi ATCC $33701 \mathrm{P}$ - (vapA negative) were used as controls. The specificity of the PCR technique was evaluated using three $R$. equi related bacterial isolates (Streptococcus sp., Nocardia asteroides and Pasteurella multocida) related to $R$. equi. All isolates were kept lyophilized until submitted to DNA extraction.

\section{DNA extraction}

Each isolate was, cultured in 5\% ovine blood agar (DIFCO), and transferred to Mueller-Hinton agar (DIFCO) and incubated at $37^{\circ} \mathrm{C}$ for 24 hours. The colonies were suspended in $500 \mu \mathrm{l}$ of milli-Q water and boiled for 10 minutes. The suspension was centrifuged at $13.500 \mathrm{rpm}$ for 3 minutes and $2 \mu \mathrm{l}$ of the supernatant were used as DNA template for multiplex PCR (16).

\section{Multiplex PCR}

The primers used in this study for amplification of $16 \mathrm{~S}$ ribosomal RNA and vapA genes fragments were respectively: RG-Forward (CGT CTAATACCG GAT ATG AGC TCC TGT C); RG-Reverse (CGCAAG CTT GGG GTT GAGCCCCAA) (1) and vapA-Forward (GAC TCT TCA CAA GAC GGT); vapA-Reverse (TAG GCG TTG TGC CAG CTA) (19). The conditions tested for multiplex PCR standardization were adapted from Takai et al. (19), with adjustments on primers and magnesium chloride concentrations, as well as temperature for amplification. All conditions were tested three times. Samples were submitted to 35 cycles $\left(30 \mathrm{~s}\right.$ at $94^{\circ} \mathrm{C}, 30 \mathrm{~s}$ at $56^{\circ} \mathrm{C}$ and $90 \mathrm{~s}$ at $72^{\circ} \mathrm{C}$ ) followed by 10 minutes at $72^{\circ} \mathrm{C}$. The products $(7 \mu \mathrm{l})$ were applied to a $1.5 \%$ agarosis gel and submitted to electrophoresis per 30 minutes at $100 \mathrm{~V}$. After stained with ethidium bromide, the bands were visualized in ultraviolet light.

The vapA and $16 \mathrm{~S}$ ribosomal RNA amplified fragments were purified from agarosis gel with polietileneglicol (16) and submitted to sequencing in an automatic DNA sequencer (MEGABACE 1000) at the Molecular Biology Laboratory, Federal University of Santa Maria.

\section{RESULTS}

In this study, the best PCR amplifying condition was achieved using $30 \mathrm{pmol}$ of RG primers, 90 pmol of vapA primers and $2.5 \mathrm{mM}$ of $\mathrm{MgCl}_{2}$, showing both for $16 \mathrm{~S}$ ribosomal RNA (468 pb) and vapA (564 pb) genes fragments amplification (Fig. 1). The length of the DNA fragments amplified by multiplex PCR were in accordance with previous results $(2,18)$. The identity of the PCR products was sustained by DNA sequencing analysis. $N$. asteroides, Streptococcus sp. and P. multocida, tested by the PCR assay presented no amplification, validating the multiplex PCR specificity.

The multiplex PCR results are shown in Table 1 and Fig. 1. Ten $(100 \%)$ isolates obtained from sick foals and seven (6.54\%) from adults and foals feces were positive for both vapA and $16 \mathrm{~S}$ ribosomal RNA, denoting the virulence potential of these strains to susceptible foals. Most pathogenic isolates were obtained

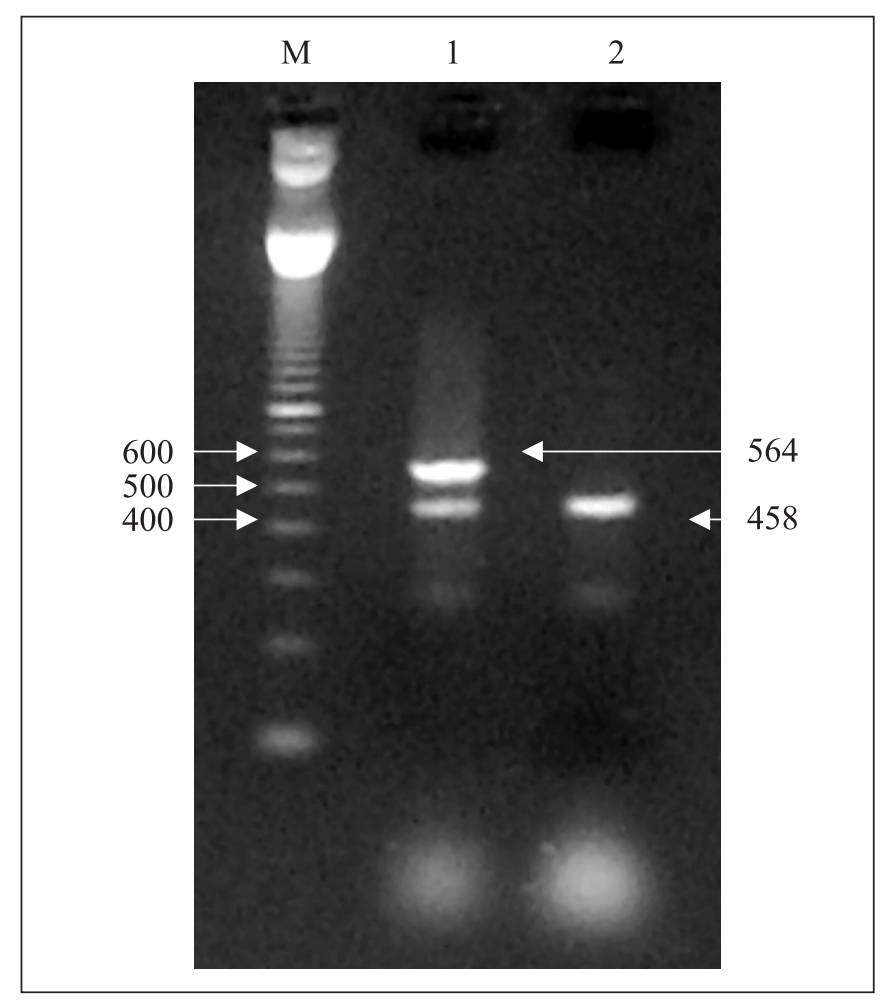

Figure 1. Multiplex PCR amplification of both $16 \mathrm{~S}$ rDNA and vapA gene fragments. L: Mollecular ladder (Ladder $100 \mathrm{pb}$ Ludwigbiotec), 1: ATCC 33701P+, 2: ATCC 33701P-. Fragments sizes are indicated in base pairs $(\mathrm{pb})$. 
Table 1. Molecular characterization of R. equi isolated from horse breeding farms in Bagé, RS, Brazil, by multiplex PCR for 16S ribosomal RNA and vapA gene fragments.

\begin{tabular}{|c|c|c|c|c|c|}
\hline \multirow[t]{2}{*}{ Farm } & \multirow[t]{2}{*}{ Disease Occurrence } & \multirow[t]{2}{*}{ Source } & \multirow[t]{2}{*}{ Total } & \multicolumn{2}{|c|}{ PCR results positive } \\
\hline & & & & $16 \mathrm{SrDNA}$ & vapA \\
\hline \multirow[t]{7}{*}{1} & Sporadic & Soil & 5 & 5 & 0 \\
\hline & & Adults equine feces & 8 & 8 & 1 \\
\hline & & Foal feces & 9 & 9 & 0 \\
\hline & & Foaling Stalls & 2 & 2 & 0 \\
\hline & & Bovine feces & 1 & 1 & 0 \\
\hline & & Chicken feces & 1 & 1 & 0 \\
\hline & & & 26 & & \\
\hline \multirow[t]{6}{*}{2} & Sporadic & Soil & 3 & 3 & 0 \\
\hline & & Adults equine feces & 10 & 10 & 1 \\
\hline & & Foal feces & 4 & 4 & 0 \\
\hline & & Foaling Stalls & 1 & 1 & 0 \\
\hline & & Clinical samples & 1 & 1 & 1 \\
\hline & & & 19 & & \\
\hline \multirow[t]{5}{*}{3} & Sporadic & Soil & 4 & 4 & 0 \\
\hline & & Adults equine feces & 8 & 8 & 1 \\
\hline & & Foals feces & 8 & 8 & 0 \\
\hline & & Foaling Stalls & 1 & 1 & 0 \\
\hline & & & 21 & & \\
\hline \multirow[t]{6}{*}{4} & Endemic & Soil & 3 & 3 & 0 \\
\hline & & Adults equine feces & 11 & 11 & 3 \\
\hline & & Foals feces & 6 & 6 & 1 \\
\hline & & Foaling Stalls & 4 & 4 & 0 \\
\hline & & Clinical samples & 9 & 9 & 9 \\
\hline & & & 33 & & \\
\hline \multirow[t]{6}{*}{5} & Not reported & Soil & 2 & 2 & 0 \\
\hline & & Adults equine feces & 3 & 3 & 0 \\
\hline & & Foals feces & 4 & 4 & 0 \\
\hline & & Foaling Stalls & 2 & 2 & 0 \\
\hline & & Bovine Feces & 1 & 1 & 0 \\
\hline & & & 12 & & \\
\hline \multirow[t]{4}{*}{6} & Not reported & Soil & 4 & 4 & 0 \\
\hline & & Adults equine feces & 1 & 1 & 0 \\
\hline & & Foal feces & 2 & 2 & 0 \\
\hline & & & 7 & & \\
\hline \multicolumn{2}{|c|}{ Total of $R$. equi isolates } & & 118 & & \\
\hline
\end{tabular}

from the same endemic horse breeding farm (Fig. 2): Virulent $R$. equi were isolated from nine $(90 \%)$ sick foals and from four $(66.6 \%)$ samples of faecal matter from healthy adults and foals. Other two virulent isolates (one from sick foal and one from adult animal feces) were obtained in two other farms ( 1 and 2), which report sporadic occurrence of Rhodococosis. Virulent $R$. equi strains were isolated in adult horses feces from farms 1,2,3 and 4 (Fig. 2).

\section{DISCUSSION}

The multiplex PCR technique described in this study has proven to be effective for the $R$. equi molecular characterization. Additionally, the epidemiological status (endemic, sporadic or no infection) of horse breeding farms from Bage County, RS, Brazil (Table 1 and Fig. 2) could be confirmed using both 


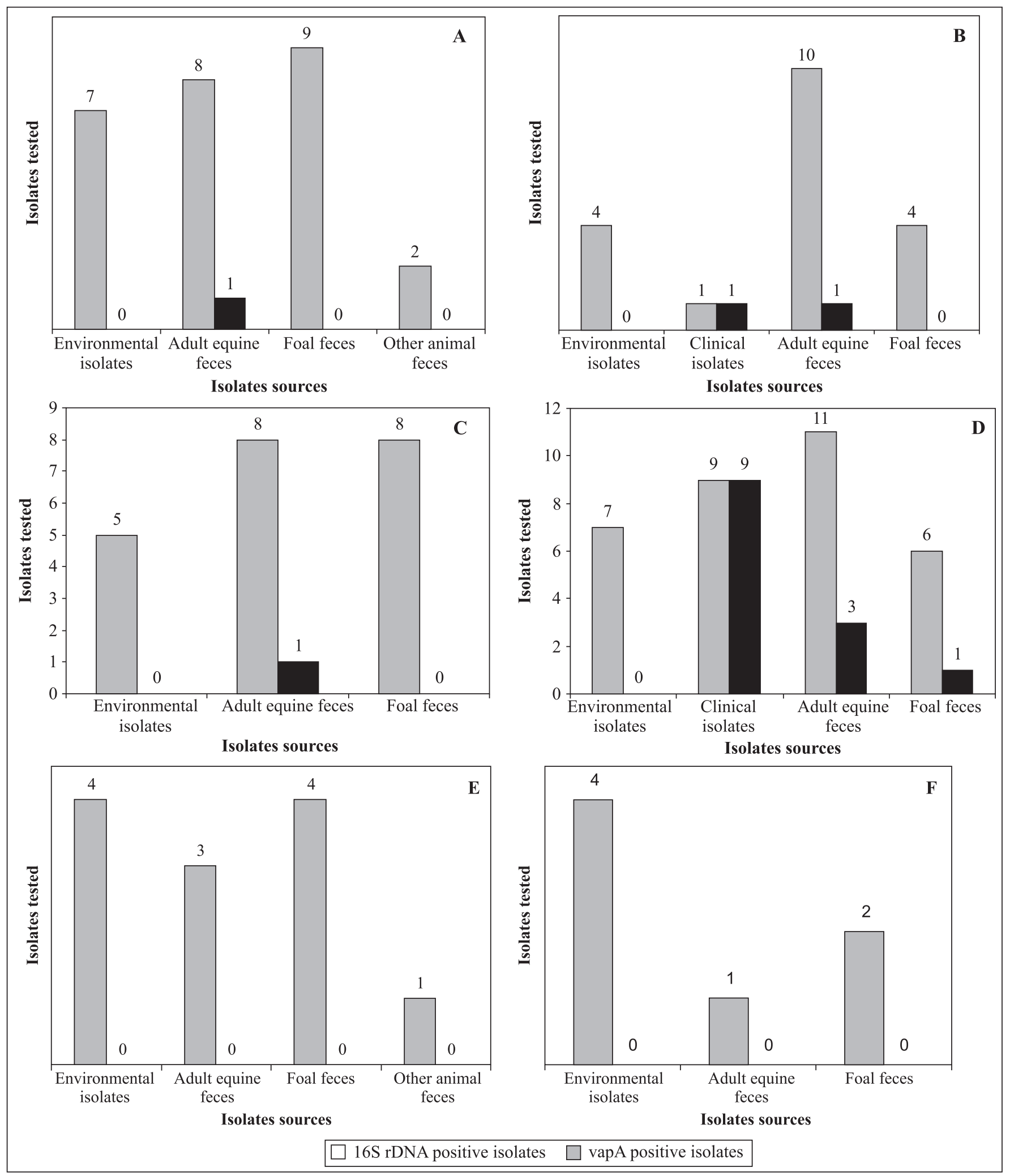

Figure 2. Prevalence of R. equi vapA-positive isolates in different horse breeding farms in Bage County, RS .A: Farm 1, B: Farm 2, C: Farm 3, D: Farm 4, E: Farm 5, F: Farm 6. 
environment (soil and foaling stalls) and horse samples (from sick and healthy animals).

The virulence-associated antigens (VapA) and plasmids are widely used as epidemiological markers of $R$. equi virulence for foal and experimentally infected mice $(6,22)$. The relationship between the presence of vapA gene and the lethality of R. equi to susceptible foals and mice was reported by many researchers $(19,21,25)$. In the present study, most virulent $R$. equi isolates were from the endemic horse breeding farm. This can be explained by the higher soil contamination, coming mainly from diarrheic feces from ill animals $(12,18)$.

The $R$. equi isolation from horse breeding farms, where occurrence of disease, is sporadic indicate that adoption of prophylactic measures to decrease the incidence of this infection is required $(12,19)$. The multiplex PCR was also important to determine the sources of infection and the importance of virulent isolates on epidemiological aspects of Rodococosis in horse breeding farms from Bage, RS, Brazil. The usefulness of vapA gene or virulence plasmid to determine the risk of $R$. equi infection was demonstrated by Takai et al. (21).

The molecular characterization of $R$. equi in this study indicated the occurrence of vapA-positive isolates in stools of animals, with no clinical signs associated to $R$. equi infection. In this way virulent $R$. equi were found in adult horse feces, confirming that the prevalence of $R$. equi infection is associated with the presence and number of virulent microorganisms in the environment and animal feces $(12,17)$. Takai et al. (21) reported that sick foals are the major source of virulent bacteria for the environment, since $R$. equi is a teluric bacterium that can multiply both in soil and gastrointestinal tract, supporting a cycle involving horses and their environment $(9,14)$. Halbert et al. (7) demonstrated that $97 \%$ of $R$. equi isolates from foals were vapA-positive, suggesting that these animals are important for the transmission of this infection. In contrast, this study demonstrates that not only foals, but healthy adult horses can carry virulent $R$. equi in their feces and spread them in their environment, indicating that these animals play an important role as a source of contamination of susceptible foals. Future studies are needed to evaluate the potential of multiplication of $R$. equi in the intestinal tract of adult horses.

\section{RESUMO}

\section{PCR multiplex para caracterização molecular de isolados de Rhodococcus equi provenientes de haras de uma região endêmica no Sul do Brasil}

Rhodococcus equi é um coco-bacilo gram positivo que causa pneumonia em potros. Trata-se de um patógeno oportunista amplamente detectado no ambiente e isolado de várias fontes, como solo, fezes e intestino de potros doentes e sadios. $\mathrm{O}$ presente estudo visa caracterizar a situação epidemiológica de criatórios eqüinos da região de Bagé, RS, Brasil, pela técnica de PCR multiplex. Cento e dezoito isolados de $R$. equi foram identificados por testes bioquímicos e, posteriormente, submetidos a um PCR multiplex para caracterização da espécie e da presença do gene vapA. Estes isolados eram provenientes de três haras com histórico da doença, dois haras onde não havia casos da doença e uma propriedade onde a infecção por $R$. equi é relatada frequentemente. Todos os isolados clínicos provenientes de haras onde a doença é endêmica e/ou esporádica foram vapA positivos. Nenhum isolado ambiental foi vapA positivo. Nos três haras onde a doença é esporádica, $11,54 \%$ dos isolados de fezes de eqüinos adultos foram positivos para o gene vapA. A técnica de PCR multiplex mostrou-se efetiva para caracterização epidemiológica e molecular dos criatórios equinos, estando de acordo com o histórico da propriedade. Um fato relevante demonstrado pela aplicação desta técnica foi a detecção de $R$. equi vapA positivo nas fezes de eqüinos adultos. Esta observação pode pressupor que haja outras vias de disseminação da bactéria dentro de uma propriedade.

Palavras-Chave: Rhodococcus equi, PCR multiplex, broncopneumonia, epidemiologia

\section{REFERENCES}

1. Bell, K.S.; Philip, J.C.; Christofi, N.; Aw, D.W.J. (1996). Identification of Rhodococcus equi7 using the polymerase chain reaction. Lett. Appl. Microbiol., 23: 72-74.

2. Byrne, B.A.; Prescott, J.F.; Palmer, G.H.; Takai, S.; Nicholson, V.M.; Alperin, D.C.; Hines S.A. (2001). Virulence plasmid of Rhodococcus equi contains inducible gene family encoding secreted proteins. Infect. Immun., 69(2): 650-656.

3. Cohen, N.D.; O'Connor, M.S.; Chaffin, M.K.; Martens, R.J. (2005). Farm characteristics and management practices associated with development of Rhodococcus equi pneumonia in foals. J. Am. Vet. Med. Assoc., 226, 404-413.

4. Costa, M.M.; Machado, S.A.; Krewer, C.C.; Ilha, M.R.S; Graça, D.L.; Mattos-Guaraldi, A.L.; Vargas, A.C.V. (2006). Pathogenicity of Rhodococcus equi in mice, isolated from environment, human and horse clinical samples. Pesq. Vet. Bras., 26, 167-170.

5. Giguère, S.; Prescott, J.F. (1997). Clinical manifestations, diagnosis, treatment, and prevention of Rhodococcus equi infections in foals. Vet. Microbiol., 56, 313-334.

6. Halbert, N.D.; Reitzel, R.A.; Martens, R.J.; Cohen, N.D. (2005). Evaluation of a multiplex polymerase chain reaction assay for simultaneous detection of Rhodococcus equi and the vapA gene. Am. J. Vet. Res., 66, 1380-1385.

7. Hondalus, M.K. (1997). Pathogenesis and virulence of Rhodococuus equi. Vet. Microbiol., 56, 257-268.

8. Kanaly, S.T.; Hines, S.A.; Palmer, S.A. (1993). Failure of pulmonary clearance of Rhodococcus equi infection in CD4+ T-lymphocytedeficient transgenic mice. Infect. Immun. 61, 4929-4932.

9. Lazzari A.; Vargas A.C.; Dutra V.; Costa M.M.; Flores L.A.S. (1997). Aspectos epidemiológicos do Rhodococcus equi em eqüinos do município de Bage, RS, Brasil. Cienc. Rural, 27, 441-446.

10. Machang'u, R.S.; Prescott, J.F. (1991). Role of antibody to extra cellular proteins of Rhodococcus equi in protection against $R$. equi pneumonia in foals. Vet. Microbiol., 26, 323-333. 
11. Makrai, L.; Takai, S.; Tamura, M.; Tsukamoto, A.; Sekimoto, R.; Sasaki, Y.; Kakuda T.; Tsubaki, S.; Varga, J.; Fodor, L.; Solymosi N.; Major A. (2002). Characterization of virulence plasmid types in Rhodococcus equi isolates from foals, pigs, humans and soil in Hungary. Vet. Microbiol., 88, 377-384.

12. Martens, R.J.; Takai, S.; Chen, N.; Chaffin, M.K.; Liu, H.; Sakurai, K.; Sugimoto, H.; Lingsweiler, S.W. (2000). Association of disease with isolation and virulence of Rhodococcus equi from farm soil and foals with pneumonia. JAVMA, 217, 220-225.

13. Meijer, W.G.; Prescott, J.F. (2004). Rhodococcus equi. Vet. Res., 35 , 383-396.

14. Prescott, J.F. (1991). Rhodococcus equi: an animal and human pathogen. Clin. Microbiol. Rev., 29, 2696-2700.

15. Quinn, P.J. (2005). Gênero Rhodococcus. In: Microbiologia Veterinária e Doenças Infecciosas. Artmed, Porto Alegre, 324-334.

16. Sambrook, R.; Russel, D.W. (2001). Molecular Cloning: a laboratory manual. $3^{\text {rd }}$ ed. Cold Spring Harbor Laboratory Press, New York, 3v.

17. Takai, S.; Anzai, T.; Yamaguchi, K.; Kakisaki, S.; Takahagi, J.; Sato, Y.; Takehara, F.; Tamada, Y.; Matsukura, S.; Tani, A.; Kato, M.; Seno, N.; Sasaki, Y.; Tsubaki, S.; Kamada, M. (1994). Prevalence of virulence plasmids in environmental isolates form Rhodococcus equi from horse-breeding farms in Hokkaido. J. Eq. Sci., 5, 21-25.

18. Takai, S.; Sasaki, Y.; Tsubaki, S. (1995a). Rhodococcus equi infections in foals - current concepts and implication for future research. $J$. Eq. Sci., 6, 105-119.
19. Takai, S.; Ikeda, T.; Sasaki, Y.; Watanabe, Y.; Ozawa, T.; Tsubaki, S.; Sekisaki, T. (1995b). Identification of virulent Rhodococcus equi by amplification of gene coding 15 to 17 Kilodalton antigens. $J$. Clin. Microbiol., 33, 1624-1627.

20. Takai, S.; Fukunaga, N.; Ocshiai, S.; Sakai, T.; Sasaki, Y.; Tsubaki, T. (1996). Isolation of virulent and intermediately virulent Rhodococcus equi from soil and sand on parks and yards in Japan. J. Vet. Med. Sci., $58,669-672$.

21. Takai, S. (1997). Epidemiology of Rhodococcus equi infections: a review. Vet. Microbiol., 56,167-176.

22. Takai, S.; Shoda, M.; Sasaki, Y.; Tsubaki, S.; Fortier, G.; Pronost, S.; Rahal, K.; Becu, T.; Begg, A.; Browining, G.; Nicholson, V.M.; Prescott, J.F. (1999). Restriction fragment length polymorphisms of virulence plasmids in Rhodococcus equi. J. Clin. Microbiol., 37 , 3417-3420.

23. Van Der Kolk, H.; Kraus, H.; Vink-Nooteboom, M. (1999). Rhodococcus equi pneumonia in foal. Equine Pract., 21, 6-9.

24. Vargas, A. (2001). Infecções por Rhodococcus equi. In: Riet-Correa, F.; Schild, A.L.; Mendez, A.M.C.; Lemos, R.A.A. Doenças de Ruminantes e Equinos. $2^{\circ}$ Ed. Varela.

25. Wada, R.; Kamada, M.; Anzai, T.; Nakanishi, A.; Kanemaru, T.; Takai, S.; Tsubaki, S. (1997). Pathogenicity and virulence of Rhodococcus equi in foals following intratracheal challenge. Vet. Microbiol., 56, 301-12. 